\title{
RESEARCH ESSAY
}

\section{The business of getting high: head shops, countercultural capitalism, and the marijuana legalization movement}

\author{
Joshua Clark Davis* \\ History Department, University of Baltimore, MD, USA
}

In the late 1960 s and 1970 s, countercultural entrepreneurs in the United States sold paraphernalia for enhancing LSD trips or for smoking marijuana at small stores called head shops. These accessories of alternative lifestyles provided hippies with a totemic material culture they could call their own. Head shop owners hoped their countercultural wares and atmosphere would provide hippies with desperately needed public spaces where they could gather in peace without being harassed. More importantly, these entrepreneurs believed their products allowed people to alter their minds - and even their societies - through meaningful drug use. In addition, many head shops made vital contributions to the movement to undermine, reform, and eradicate America's drug laws. While these businesses were not opposed to turning a profit, their communitarian idealism and political engagement contradict the common charge that so-called hip capitalists were little more than apolitical sell-outs and dupes. Both head shops and the marijuana legalization movement helped each other achieve remarkable levels of financial and political success in the middle of the 1970s. In contrast to their predecessors of the late 1960s, many head shops of the late 1970s embraced profit and financial growth and deemphasized radical politics and counterculture. By the end of the decade, head shops numbered an estimated 30,000 and organized their own trade groups and meetings. Eleven states even decriminalized minor personal possession of marijuana in the 1970s. Although head shops had always faced scrutiny from police and concerned private citizens, it was only at the end of the 1970s that parents' groups and legislators began to coordinate a national campaign against the so-called "commercialized drug culture" they attributed to these countercultural entrepreneurs. Consequently, the crusade against head shops represented one of the first salvos in the cultural and legislative War on Drugs of the 1980s.

Keywords: head shops; counterculture; hip capitalism; marijuana; marijuana legalization movement; social movements; public space; hippies; drugs; War on Drugs; drug paraphernalia; business; entrepreneurship; Haight-Ashbury; High Times

\section{I}

In September 1970, the Wall Street Journal reported with palpable suspicion on a rather unusual retailer in Lansing, Michigan called the Free Spirit, "a highly imaginative, though not entirely problem-free, mod department store." The Free Spirit was a curious oddity compared to the other businesses, including a Jewish deli and an African American funeral parlor, which the Journal had favorably profiled in its ongoing series on the country's "neighborhood merchant." Unlike these stores,

*Email: jdavis@ubalt.edu 
which operated in long-established markets, the Free Spirit served a young, rebellious clientele seeking unconventional products: "Stocked within its doors are the furnishings and paraphernalia of the 'turned-on, tuned-in' generation, goods that most other merchants shun as too far out." There were several different departments in this "mod boutique," but the merchandise that most caught the Journal's attention were the "pet lizards on leashes, incense, Eldridge Cleaver wanted posters and even cigarette paper for wrapping marijuana" - all of which could be found in an area of the Free Spirit that customers would have called a "head shop."2

Jay Hanson, the Free Spirit's owner, had grown dissatisfied with the venerable department stores like Knapp's and Liebermann's in downtown Lansing's retail core that were "just coming out of the 19th century." Hanson wanted to offer a more vibrant and dynamic shopping experience, one that appealed to young people in search of new freedoms and insights. "I'm a capitalist, but not in the true sense of the word. We feel a responsibility to our culture. We aren't totally profit oriented [and] our customers are our friends," Hanson argued. "The role of the Free Spirit ... is a cultural meeting place of young and old, rich and poor," he explained. "Everything's different" at the Free Spirit, a college student browsing the store remarked. "You walk in ... and you feel really free." The Journal affirmed the store's distinctiveness in more critical terms: "Rock music pervades the store" and salesclerks dressed "casually, even sloppily." Customers were "encouraged to come in and just 'rap' about the draft or civil-rights or anything else on their mind," even if they didn't want to make a purchase. ${ }^{3}$

In the late 1960s and 1970s, Hanson and countless other "hip capitalists" established head shops as an alternative to American's dominant consumer culture, a culture they believed was alienating, conformist, uptight, and "plastic." In major cities and college towns across America, head shops appealed to a new generation of cultural rebels to purchase products that were purportedly hip or psychedelic, including paraphernalia for enhancing LSD trips or for smoking marijuana. These accessories of alternative lifestyles provided hippies, freaks, and longhairs with a totemic material culture they could call their own. Head shop owners hoped their countercultural wares and atmosphere would provide hippies with desperately needed public spaces where they could gather without being harassed. More importantly, they believed these products allowed people to alter their minds - and even their societies - through meaningful drug use. As David Farber has argued, running a countercultural business represented to many people not just a job, but a calling, as well as a precious opportunity to achieve self-sufficiency through communityminded enterprise. Consequently, some countercultural entrepreneurs would adopt the term "right livelihood" by the early 1970 s to describe this missionary zeal for enlightened labor. ${ }^{4}$ Indeed, head shops were just one kind of activist and politically engaged businesses that flourished in the 1960s and 1970s, including natural foods groceries, Black Power bookstores, and feminist storefronts. 5

While scholars have begun just recently to address so-called hip capitalists' pivotal role in countercultural community building, they have largely overlooked these businesses' extensive political activism. Critics have not been entirely unjustified in claiming that some countercultural businesses valued profit as much as or more than politics. ${ }^{6}$ After all, some hippie entrepreneurs openly admitted they were capitalists striving for financial success. ${ }^{7}$ Yet many head shops made vital contributions to the movement to undermine, reform, and eradicate America's drug laws. ${ }^{8}$ 
Marijuana reform groups like Amorphia and the National Organization for the Reform of Marijuana Laws spearheaded major campaigns for decriminalization with proceeds from paraphernalia they sold through head shops. Head shop owners distributed written materials on drug legalization in their stores and donated generously to reform groups. In addition, head shops' blatant endorsement of illicit activity resonated deeply with young Americans who distrusted a federal government they believed was both waging an immoral and illegal war in Vietnam and enforcing unjust drug laws. If smoking pot and dropping acid were powerful forms of political protest or even revolution against the American state and the country's repressive cultural norms - as a number of voices in the New Left and counterculture maintained - then it followed that head shops, by selling accessories to help people get high, were key accomplices in such acts of resistance. ${ }^{9}$ In short, head shops were deeply political spaces at the forefront of the struggle against punitive drug laws and repressive state power.

Both head shops and the marijuana legalization movement helped each other achieve remarkable levels of financial and political success in the middle of the 1970 s, which they owed to spiraling rates of marijuana use as well as the rise of High Times, the nationally popular magazine "dedicated solely to getting high."10 In contrast to their predecessors of the late 1960s and early 1970s, many head shops of the late 1970s embraced profit and financial growth and deemphasized radical politics and counterculture. By the end of the decade, head shops numbered an estimated 30,000 and organized their own industry groups and trade meetings. Eleven states even decriminalized minor personal possession of marijuana in the 1970s. ${ }^{11}$

As public sites associated with hippies and drug culture, these businesses generated considerable controversy. From the late 1960s onward, law enforcement officers monitored, investigated, and raided head shops, while private citizens subjected them to lawsuits, pickets, and even physical attacks. For most of the 1970 s, isolated local efforts did little to slow head shops' remarkable growth across the country. Yet by 1979, local parents' groups began to coordinate a national campaign against the so-called "commercialized drug culture" spawned by head shops, which they charged with fueling a pandemic of youth marijuana abuse. In response, states and cities across the country passed countless laws designed to severely restrict head shops and even put them out of business. Indeed, the crusade against head shops represented one of the first salvos in the cultural and legislative War on Drugs that would unfold in the 1980s. Thousands of head shops would close over the course of the decade, and many of those that remained open survived by retreating even further from their earlier celebration of cultural rebellion and political resistance. In many ways, head shops have never fully recovered. Even as several states have recently passed legalization measures and a new generation of highly capitalized marijuana entrepreneurs present themselves as conventional entrepreneurs, head shops' role as centers of countercultural community and advocates for drug law reform remains greatly diminished. Nonetheless, the history of head shops provides a revealing window into how countercultural entrepreneurs who embraced drug culture exerted a remarkable influence on American society and politics from the late 1960 s to the early 1980 s. 


\section{II}

In 1964, Jay Thelin attended a lecture at San Francisco State University about LSD by Richard Alpert, whose experiments with acid had resulted in his and Timothy Leary's dismissal from Harvard University the previous year. Alpert, Leary, and Harvard psychology graduate student Ralph Metzner had recently co-authored The Psychedelic Experience: A Manual Based on the Tibetan Book of the Dead, in which they urged readers to take up psychedelics to liberate themselves "from their life-long internal bondage."12 Jay was riveted by Alpert's talk, and in the coming months he and his brother Ron tried LSD for the first time. Acid proved to be nothing less than a revelation for them.

Ron and Jay lived in Haight-Ashbury, a quiet and affordable San Francisco neighborhood where blacks and whites, working-class and middle-class families lived side by side. By 1965, however, the neighborhood was beginning to change. As a San Francisco Examiner article reported, the Haight was becoming the city's "new bohemian quarter" and attracting "the outer fringe of the bohemian fringe." These people, according to the reporter, were "the 'hippies,' the 'heads,' the beatniks." ${ }^{\prime 3}$ It was amid this transition that Ron and Jay Thelin opened the Psychedelic Shop at 1535 Haight Street. The neighborhood already had a few hip businesses, including the Blue Unicorn coffee house and two boutiques, House of Richard and Mnasidika. But the Thelins' business was highly unusual even for the Haight. With their storefront, the Thelins hoped to "provide materials necessary for a good, enlightened, and safe trip."14 These materials included "books on eastern religion and metaphysics ... along with Indian records, posters, madrases, incense, bead necklaces, small pipes, and other paraphernalia," as described by the poet Allen Cohen, an early customer and later employee of the store. ${ }^{15}$ A wide array of seemingly incompatible goods, each of these items was believed to heighten and enhance the effects of both LSD and marijuana. ${ }^{16}$ Although the Thelins recognized the potential dangers of LSD, which was still legal in California, they believed that people could benefit enormously from acid with the proper preparation and information, especially if they could take it with friends in a safe, supportive environment that was complemented by pleasant lighting and music. ${ }^{17}$

The Psychedelic Shop opened its doors on 3 January 1966, quickly attracting the Haight's young cultural rebels in search of a community space that unconditionally welcomed them. People came in to the store to talk politics, religion, and, of course, about their experiences taking acid and marijuana. The shop's bulletin board featured flyers seeking and offering housing, work, band mates, or activity groups. The store was also a popular place for customer to leave notes for friends, many of whom did not have easy access to phones. Others simply passed time by sitting on the store's floor or on the sidewalk outside. ${ }^{18}$ By fall 1966, the Psychedelic Shop had become among the most important public spaces for the Haight's burgeoning countercultural scene, second perhaps only to Golden Gate Park's Hippie Hill and Panhandle sections.

More and more, the Thelins saw themselves and their shop as agents for social change. Frustrated by the US's increasing military involvement in Vietnam as well as the growing white backlash to the non-violent civil rights movement, the brothers thought LSD could provide Americans the formula for achieving true peace and equality. Ron also felt that modern capitalism debased and deeply alienated the American people. "The economy, the tyranny of money, the fight for material 
things," he remarked, "has become the American dream - and the dream of the Declaration of Independence is completely washed up in an advertising gimmick." ${ }^{\prime 19}$ As Jay explained further,

The reason we can no longer identify with the kinds of activities that the older generation are engaged in is because those activities are for us meaningless. They have led to a monstrous war in Vietnam, for example. And that's why it's all related - the psychedelics and the war, the protesting, the gap in the generations. ${ }^{20}$

These developments "were not answering the promise of America," Jay and Ron believed. "Psychedelics and getting high," they felt, "would be the catalyst that would change everything," and the Psychedelic Shop would be the primary means of spreading that message in San Francisco. Like many people in San Francisco's countercultural community, the Thelins saw the Old and New Left's traditional tactics as having a limited impact on American social values, compared to the fundamental psychological and emotional transformation they believed LSD could achieve. $^{21}$

Despite their skepticism about traditional forms of engagement, the Thelins were politically active, although in a deeply unconventional sense. In June 1966, the California Legislature voted to prohibit the possession of LSD on 6 October that year. Ron joined forces with the artist Michael Bowen and Psychedelic Shop employee Allen Cohen to organize a "Love Pageant Rally" to take place on the first day of California's LSD ban. Writing in the Haight's underground newspaper, The San Francisco Oracle, which Bowen and Cohen co-founded and Thelins partly funded, the three men announced the event with a "Declaration of Independence" in a full-page notice topped by an illustration of a marijuana leaf. The three organizers urged readers "to cease to recognize the obsolete social patterns which have isolated man from his consciousness and [instead] to create with the youthful energies of the world revolutionary communities of harmonious relations." By attending the Love Pageant, people could protest LSD's prohibition as well as affirm their "inalienable rights," including "the freedom of the body, the pursuit of joy, and the expansion of consciousness." 22 On 6 October, an estimated 700 to 800 people showed up at Golden Gate Park to translate "this prophesy into political action" and demonstrate against the new LSD ban by dropping hundreds of tabs of acid in unison. $^{23}$

Meanwhile, the Psychedelic Shop was inspiring a host of imitators in the Haight. As Time magazine reported in February 1967, "psychedelic central for the U.S. right now is a half-mile stretch along San Francisco's Haight Street, which has 27 shops catering to the needs of hippies and trippies" with a variety of "incense, cigarette papers and bells." 24 Several similar stores had opened in New York's East Village, too, including one called the Psychedelicatessan and another called simply the Head Shop. These businesses, one sociologist argued, "fulfilled a number of primary community functions" for their neighborhoods' hippies and "in a loosely analogous sense [were] a combination of church, community center, and public drinking place in the straight world." 25

Yet as the Thelins' business model proved ever more successful, the brothers lost what little interest they had in turning a profit. Now, more than ever, the Thelins aspired to make the Psychedelic Shop a headquarters for hippies seeking community and enlightenment, as well as a refuge from the increasingly rough 
streets in the Haight. When a terrible fire devastated an apartment above the store, firefighters extinguished the blaze, but in the process waterlogged and ruined a significant portion of the Psychedelic Shop's merchandise. Instead of replacing their lost merchandise, Ron and Jay set up a space for meditation in the shop, which they christened the Calm Center. In the coming months, it would regularly host members of the nearby Hare Krishna temple, who, as Jay remembered, would "come into the meditation room and chant and the kids could come in off the street and join them." 26 The Thelins also announced plans to incorporate the store as a non-profit and sell shares on the streets of the Haight for mere pennies. ${ }^{27}$ These changes did not boost the Psychedelic Shop's revenues. Fewer paying customers came to the store, so the Thelins reduced their hours. Many people took advantage of the Calm Center for meditating or coming off bad acid trips, but some used it as a place for sleeping, smoking marijuana, and selling drugs, against the Thelins' wishes. As one historian of the Haight declared, the Psychedelic Shop had become "essentially a bustable crash pad at the most highly publicized address on Haight Street." 28

By the middle of 1967 - the so-called Summer of Love - the day-to-day pressures of running the world's leading psychedelic storefront began to wear on the Thelins. The influx of an estimated 100,000 young people absolutely overwhelmed the Haight, transforming the neighborhood's modest homelessness problem into an outright crisis. Violence and the use of hard drugs, including methamphetamines and heroin, rose to unprecedented levels. ${ }^{29}$ Burnt out and dispirited, a group of 80 people, including staffers from the Psychedelic Shop, commemorated the "death of the hippie" on 6 October 1967. Organizers held a wake for a handmade mannequin of a hippie, carrying him in a cardboard coffin down Haight Street as "Taps" played and marijuana and beads burned in a funeral pyre. The march concluded at the Psychedelic Shop, which Ron Thelin announced was permanently closing. Not only that, but Ron told the marchers the store was giving away its entire inventory, and he invited them to take anything they wanted without paying a cent - a decision he made without his brother's consent. ${ }^{30}$

At the time of the closing, Ron and Jay had fashioned the Psychedelic Shop into one of the most idealistic and high-minded countercultural businesses of its time. "The mass media made us into hippies. We wanted to be free men and build a free community," Ron lamented. "[But] that word hippy turned everyone off ... Well, the hippies are dead." 31 In the window of the Psychedelic Shop hung several handwritten signs with the messages "Be Free," "Don’t Mourn for Me, Organize," and, most provocatively, "Nebraska Needs You More that the Haight."32

\section{III}

While few if any head shops would ever achieve the international renown of the Psychedelic Shop, the Thelins' idealistic countercultural store nonetheless proved an alluring model for many aspiring hippie entrepreneurs. Businesses like the Thelins', in fact, were opening all over the country. As one cautionary profile of America's "drug scene" in 1968 reported, "in many cities psychedelic book stores, poster shops and rug shops are sprouting," and their success suggested that they had a much larger commercial potential than what the Psychedelic Shop had achieved. "Astute businessmen" purportedly thought they had discovered what could "be a 25 billion-dollar-a-year market." 33 Even Nebraska may have needed 
the Haight's hippies less than the staff of the Psychedelic Shop realized. Omaha, for example, already had a small but burgeoning countercultural scene strong enough to support hippie enterprises by late 1967. Buffalo Chip, an underground newspaper in the style of The San Francisco Oracle, was launched in Omaha that year, while a local head shop, the Farthest Outpost, sold "posters, beads, ear things, onions, amulets, roach holders, toys \& things of interest." 34

While some of these businesses called themselves "psychedelic shops," more and more opted for the term "head shop." Since at least the 1930s, avid marijuana smokers had referred to each other as "weed heads," "pot heads," or simply "heads." By the 1960s, the terms were circulated even more widely by media that showered attention on the hippie counterculture. ${ }^{35}$ Most stores that followed in Psychedelic Shop's footsteps in 1966 and 1967 opened in "hippie ghettoes" in major cities, but some began to open in college towns, including Eugene, Oregon; Amherst, Massachusetts; and Austin and Denton, both in Texas, by 1968. At the end of the decade, cities like New York, San Francisco, and Los Angeles were each home to dozens of head shops, while smaller cities like Miami, Cleveland, Baltimore, and Atlanta could claim at least several head shops, too. ${ }^{36}$

Like the Thelins, many head shop owners believed their products and services could empower people to achieve liberation through higher states of consciousness. Countercultural entrepreneurs knew that customers bought pipes, papers, posters, records, candles, black light bulbs, and even Buddhist and Hindu paraphernalia for getting high. But the experience itself of visiting a head shop was supposed to transport customers psychologically, to delight their senses, to take them on a proverbial trip. To set the mood for shoppers, stores often featured loud music, psychedelic lights, and heavy incense smoke. With names like Inner World, Middle Earth, Mind Garden, Sidereal Time, Third Eye, and The First Bardo (a reference to the Tibetan Book of the Dead), head shop owners devised their stores as places where customers could search for spiritual freedom and enlightenment. Some stores, such as the Electric Lotus in New York, featured meditation rooms like the Thelins' Psychedelic Shop. ${ }^{37}$ Indeed, many head shop owners believed they offered a more humane, enlightened, and authentic alternative to the conformity, materialism, and alienation they attributed to "plastic" American consumer culture.

To be sure, head shop owners often invested more time and energy pursuing enlightenment and community than they did developing business practices that made long-term growth possible. Accounting, inventory, and profit margins did not seem to be particularly high priorities for many head shops. "Yesterday I gave away more than I sold," one owner in Eugene, Oregon told a reporter in 1967. "I just want to make enough money to pay the rent, and to eat." As one sociologist argued in 1972, most head shops were "community-oriented shops ... offering for sale 'at cost' the accoutrements for community role performance - most especially drug "tripping." 38 Yippie leader and anti-war activist Abbie Hoffman agreed, praising head shops as "community-minded stores" in his 1971 paperback manifesto, Steal This Book. ${ }^{39}$ Customers were welcome to stop by, chat with clerks and other shoppers, and hang out - all without necessarily making any purchases. ${ }^{40}$ The Los Angeles Times described the California Stash on Melrose Avenue as a place where "one of the principle [sic] attractions ... to neighborhood hippies is that here they get 'hanging-about privileges,' and they don't have to spend any money while they're at it." 41 Other head shops were magnets for hippies seeking band mates or places to live, which they found by talking to other customers or reading ads on 
message boards. "I thought we were the housing authority," one Baltimore storeowner quipped after fielding countless questions about places to stay, "but it's just because we're a head shop that they came here." 42 In an era when strict rules still governed workplace dress and grooming and retail clerks regularly wore business attire, head shop employees embraced the casual, "natural" hippie look of long hair, jeans, and sometimes even no shirts or shoes. ${ }^{43}$ Some, although not most, shop owners sold illegal drugs and allowed customers to get high on-site. Most famously, one of the biggest hashish and LSD smuggling rings in America, the Eternal Brotherhood of Love, operated the Mystic Arts World head shop in Laguna Beach, California from around 1967 to $1970 .{ }^{44}$ Head shops may not have been the most efficient or profitable enterprises, but it was their very rejection of conventional business practices that attracted hippies and other customers seeking unconventional public spaces and alternatives to America's dominant consumer culture.

Head shops were among the few places where hippies could congregate in their communities without encountering significant hostility or outright harassment. Many traditional business owners discouraged hippies from patronizing their stores, and some even refused to serve them. ${ }^{45}$ By contrast, most head shop owners - who usually identified as hippies themselves - regarded young longhairs and freaks as their most important customers. Yet it was particularly in neighborhoods where hippies and head shops clustered that police targeted long hairs for loitering, disorderly conduct, and drug use. Law enforcement also detained countless minors in these neighborhoods in response to the emerging social problem of "runaways," or teenagers who fled from their families." 46 Yet despite such close scrutiny from police, districts like these - which some sociologists and anthropologists christened "hippie ghettoes" or "youth ghettoes" - emerged all over the country. It was in these neighborhoods where most countercultural entrepreneurs offered hippies retail spaces that doubled as unofficial community centers. ${ }^{47}$

But precisely because head shops identified so closely with the counterculture, they too drew police officers looking to make arrests and even some private citizens hoping to harass them. Head shop owners had their business licenses revoked, were subject to arrest, monitored and raided by undercover police, and in some cases even attacked with bricks and bombs by unknown assailants. ${ }^{48}$ In San Clemente, California, for instance, a petition signed by 700 residents unsuccessfully sought to persuade local officials to revoke the business license of the town's first head shop, the Mind Garden. As one of the directors of the town's Chamber of Commerce warned ominously, if the store were allowed to remain open for long, "it'll be too late, just as it already is too late for Laguna Beach, where the hippies have been allowed to crowd together in hovels." $" 49$ To many people, head shops were illegitimate, dirty businesses that disturbed public order, bred lawlessness, and drew unwanted hippies into their communities.

As one of a growing number of countercultural businesses operated by so-called "hip capitalists," head shops also faced charges from the underground press of contributing little to meaningful political or social change. "The hip merchants are always getting taken to task by the arch-anarchist-Marxists," ${ }^{\circ 0}$ remarked Tsvi Strauch, a boutique owner and water pipe seller in the Haight. "Hip capitalists remain largely apolitical," contended the author of "The Age of Acquireous," a brilliantly titled article that appeared in San Francisco's Good Times underground newspaper in 1970: "By doing business in the system, they perpetuate it and contribute taxes." ${ }^{\circ 1}$ Such critiques aligned with sentiments in the New Left and 
counterculture that the widespread popularity of pot and acid threatened to undermine the drugs' capacity for social and political change. ${ }^{52}$ The San Francisco Oracle urged readers to "not buy or sell dope anymore! ... Let's detach ourselves from that material value - Plant dope and give away all you can reap." 53 Meanwhile, as one reader of Atlanta's Great Speckled Bird underground newspaper complained in a letter, "There has been a tremendous growth of the 'hip' element in Atlanta ... [But] perhaps this situation exists because the sole basis for this new cult is dope, and not because of any enlightenment to the true ideology." ${ }^{54}$ To its critics, hip capitalism was, at best, countercultural escapism and, at worst, both surrender to cooptation and a profitable way to dodge political responsibility.

While it was true that countercultural entrepreneurs' primary interest did not lie in politics, head shops were by no means apolitical. Their owners vigorously promoted the anti-war movement, often providing free protest literature in their stores and selling anti-war paraphernalia. Some head shop owners, like Doug Brown of Oat Willie's in Austin, Texas, were actively involved in anti-war demonstrations. Head shops commonly distributed underground and New Left newspapers, which was no small feat considering the intense backlash many such publications and their sellers faced in communities across the country. ${ }^{55}$ By the end of the $1960 \mathrm{~s}$, there was a significant overlap between political protesters and members of the socalled "drug culture," namely the people who frequented head shops for rolling papers, pipes, and psychedelic accessories. Indeed, student activists were considerably more likely to smoke marijuana than non-protestors, as a 1969 Gallup Poll demonstrated. ${ }^{56}$ Such an overlap provided ample fodder for politicians, who blamed marijuana's popularity on student activists. Senator James Eastland of Mississippi claimed in hearings he held on the "marijuana-hashish epidemic and its impact on United States security" that the "epidemic began at Berkeley University at the time of the 1965 Berkeley Uprising ... [when] the right to pot became an integral part of the catalogue of demands of the uprising." 57 And as President Nixon told Elvis Presley in their famed White House meeting in 1970, "Those who use the drugs are the protestors. You know, the ones who get caught up in dissent and violence. They're the same group of young people." 58

Eastland and Nixon's dubious claims notwithstanding, many people in the counterculture did believe that LSD and marijuana were political tools they could use to free their consciousness, advance peace, and break out of the strait-jacket of repressive American cultural norms. ${ }^{59}$ As the Michigan-based countercultural leader John Sinclair argued, smoking marijuana allowed people to "see that the whole repressive political and economic and cultural machinery of the capitalist state must be dismantled and thrown on the junkheap of history," in a reformulation of Trotsky's oft quoted dictum. Marijuana, Sinclair argued further, was "a political force by virtue of the opposition it encounters from the established state." ${ }^{~}$ Meanwhile, the Yippies, best known for their countercultural political theater and involvement in the radical anti-war movement, made marijuana a central part of their political program. The Yippies' flag, for instance, featured a giant, green weed leaf. "We Are a People," a manifesto from the 2nd Yip Collective in 1970, attributed the American legal system that "put 200,000 of us in jail for smoking flowers" to "a society based on war, racism, sexism, and the destruction of the planet." ${ }^{\text {"61 }}$ The Yippies and Sinclair had a point: between 1965 and 1971, the annual total of marijuana arrests nationwide skyrocketed from less than 19,000 to more than 225,000 - an increase of over 1000 percent. $^{62}$ 
As the counterculture and New Left began to attack the social costs of punitive drug laws in the second half of the 1960s, many head shops joined the small but growing movement to decriminalize and legalize marijuana. The movement traced its origins to 16 August 1964, when a young man named Lowell Eggemeier walked into the San Francisco Police Department, lit up a joint, and announced he was protesting the prohibition of marijuana. Arrested immediately, Eggemeier hired an attorney, James R. White, III, who in turn founded the organization Legalize Marijuana, or LeMar, as part of Eggemeir's defense. Although they eventually lost the case on appeal, Eggemeier and White published a slim, 73-page volume called Marijuana Puff In, a reprint of their opening brief that LeMar distributed to bookstores and activists throughout the country. ${ }^{63}$ Later that year, several of the leading figures in New York's thriving countercultural scene in the Lower East Side and East Village - including Beat poet Allen Ginsberg, the pioneering gay rights activist Randy Wicker, and Ed Sanders of the Peace Eye Bookstore (and later the rock group the Fugs) - started their own local chapter of LeMar. Among their early activities was a small protest at the New York Women's House of Detention in 1965, where Ginsberg was photographed holding a sign that proclaimed "Pot Is Fun." The image was reproduced on a poster that would later become a popular seller at head shops. New York's LeMar chapter also published The Marijuana Newsletter, a crudely designed and partly handwritten newsletter whose stated mission was "to print position papers, medical testimonies, \& general information about the campaign to legalize marijuana! ... We have the facts about marijuana, the gentle benevolent herb." 64 Wicker, one of the Newsletter's editors, would later open and operate a successful East Village head shop, the Underground Uplift Unlimited, from around 1967 to $1971 .^{65}$

Legalization advocates' critique of drug laws as tools of political repression crystallized in campaigns to free two activists imprisoned for marijuana offenses in the late 1960s and early 1970s. In Houston, Texas, Lee Otis Johnson was a prominent African American organizer with the Southern Nonviolent Coordinating Committee. ${ }^{66}$ Beginning in 1967, Johnson was arrested five times by local police for various alleged offenses, yet each incident resulted in his release and dropped charges. Then in April 1968, two days after condemning the city's police force at a rally in the wake of Martin Luther King, Jr's assassination, Johnson was indicted for passing a joint to an undercover officer weeks earlier, an act that qualified as a drug sale in Texas. By late August, Johnson had been convicted on the testimony of the lone officer and sentenced to 30 years in prison. While Johnson languished in a Texas state penitentiary, underground and leftist media all over the country publicized his case, and activists in Texas established the Lee Otis Johnson Defense Committee, collecting over 13,000 signatures to free the man they dubbed "Houston's black political prisoner." 67 After serving four years in prison, Johnson was finally released in 1972 when a federal judge overturned his conviction. ${ }^{68}$

Yet it was the campaign to release Michigan activist John Sinclair from prison that truly galvanized the national marijuana legalization movement. Sinclair had become prominent in the second half of the 1960s in Detroit's growing countercultural community, where he cofounded the Trance-Love Energies cultural collective, managed the rock group the MC5, enthusiastically participated in the local anti-war movement, and organized a local LeMar chapter. ${ }^{69}$ Early in 1967, Sinclair and 55 other people associated with Trance-Love Energies were gathering to plan a benefit concert for marijuana legalization and a community fund for drug arrestees when 
Detroit police raided the meeting. ${ }^{70}$ Several attendees, including Sinclair, were arrested on marijuana charges, setting into motion a long series of legal maneuvers that lasted several years. It was Sinclair's third marijuana arrest, the second of which an undercover police officer had made in 1966 after weeks of surveillance. ${ }^{71}$ In 1968, as legal proceedings unfolded, John and his wife Leni established the White Panther Party, which advocated full solidarity with the Black Panther Party, denounced the draft and the carceral state, and called for a "total assault on the culture by any means necessary, including rock\&roll, dope, and fucking in the streets." 72 When Sinclair appeared before the court that April, he and his attorney challenged the charges as unconstitutional, arguing that prison time for marijuana possession represented cruel and unusual punishment. After extensive consideration, the motion to rule on the law's constitutionality was dismissed, and in July 1969 Sinclair was convicted of possession and sentenced to nine-and-a-half to ten years in prison. ${ }^{73}$ The White Panther Party and their activist allies around the country organized an International Committee to Free John Sinclair in response. Sinclair published the pamphlet Message to the People of Woodstock Nation from prison, which included a defiant call to arms to his fellow activists and hippies: "IF YOU WANT TO GET HIGH, YOU'RE GONNA HAVE TO FIGHT."74

Opponents of Sinclair's imprisonment took heed and redoubled their efforts. By early 1970, LeMar made Sinclair a "peace correspondent" for its renamed publication, Marijuana Review, and issued frequent demands for his release. ${ }^{75}$ The campaign reached its crescendo in December 1971 with a rally and benefit concert in Ann Arbor, Michigan "to demand freedom for John Sinclair and an end to marijuana prohibition." John and Yoko Ono headlined, drawing over 15,000 attendees to the city's Crisler Arena. Under intense political pressure, the Michigan Supreme Court granted Sinclair bond and released him just three days after the rally. ${ }^{76} \mathrm{Sev}-$ eral months later, in April 1972, the Court released an additional 128 prisoners convicted of marijuana possession, ruling that the state's laws did in fact, as Sinclair had argued, violate the Constitution by treating marijuana as a "hard" narcotic. ${ }^{77}$ Meanwhile, the Rainbow People's Party, an alliance of hippies and radicals that emerged out of the White Panther Party, ran a slate of candidates for the Ann Arbor City Council on the Human Rights Party (HRP) ticket that spring. Their platform advocated decriminalizing marijuana possession and repealing all laws against homosexuality. In a major upset, HRP candidates Jerry DeGrieck and Nancy Wechsler - both just 22 years old - were elected to the Ann Arbor City Council. $^{78}$ Within two months, the town's city council, led by DeGrieck and Wechsler, voted to reduce marijuana possession to a $\$ 5$ fine, making its drug laws the most liberal in the country. ${ }^{79}$

In the early 1970s, advocates of drug law reform, many of them close allies of Sinclair, came to view head shops and the paraphernalia they sold as lucrative vehicles for funding the legalization movement. Originally established as a proprietary enterprise in 1969, the California-based legalization group Amorphia reformed as a nonprofit and merged with LeMar in $1972 .{ }^{80}$ That year, the organization grew to employ about a dozen fulltime employees, including its California field director Gordon Brownell, a onetime junior staffer in the Nixon White House who had renounced a career in Republican politics after a powerful first experience with mescaline. ${ }^{81}$ By early 1973, John and Leni Sinclair joined Marijuana Review editor Mike Aldrich and New York attorney David Michaels as Amorphia's national chairs. ${ }^{82}$ The organization's primary fundraising strategy was to produce its own 
brand of rolling papers, Acapulco Gold, and sell them for about three times as much as most rolling papers. "By selling head stuff, starting with rolling papers, and donating all proceeds from such sales to this legalization campaign," announced Amorphia, "we will attempt to fund an all-out media assault on Middle Amerika for legalization of marijuana (and perhaps other drug law reform)."

Amorphia in turn appealed to legalization activists to hawk rolling papers as salespeople. "Become an 'acapulco gold' sales representative or jobber," an advertisement in Marijuana Review read. "This entails going around to head shops, bookstores, hip boutiques, and anyplace else that sells cigarette rolling papers in your area, and making sure they sell 'acapulco gold' papers." ${ }^{~} 84$ Aldrich declared that Amorphia's sales scheme was the best strategy for legalization that he had seen in five years in the marijuana rights movement. Yet proceeds from Acapulco Gold were intended to do more than just contribute to drug law reform. By entering the business of supplying head shops, Amorphia planned "to pour $\$ 30$ million a year into underground movements, social change, and the creation of a better world. Legalization is not an end; it is a means to create social change and a new form of economic organization." 85

The first major test of Amorphia's strategy was its campaign for Proposition 19, a legalization referendum in California in $1972 .{ }^{86}$ Amorphia provided the primary financial support for the initiative, contributing $\$ 50,000$ to the campaign, almost a third of which came from Acapulco Gold proceeds. Although Amorphia greatly outspent the anti-legalization groups, the referendum easily lost by a margin of almost two-to-one. Still, the final vote tally suggested that the marijuana rights movement had significant room to grow. Over a third of voters in the referendum had opted for legalization, and San Francisco County and Berkeley both approved the measure. ${ }^{87}$ Amorphia later contributed to legalization efforts in several other states, including Michigan and Washington. And while a referendum campaign Amorphia funded to fully legalize marijuana in Oregon failed in 1972, it did spur the state's legislature to form a committee to study, and ultimately recommend, decriminalizing marijuana. The following year, in 1973, Oregon's legislature voted to make the state the first in the country to eliminate criminal penalties for marijuana possession. ${ }^{88}$

By 1973, another group, the National Organization for the Reform of Marijuana Laws, or NORML, was vying for leadership of the legalization movement. Founded in 1970 by Keith Stroup, a young consumer attorney and former staffer of the congressionally mandated National Committee on Product Safety, NORML had virtually no budget until Stroup successfully lobbied Hugh Hefner's philanthropic Playboy Foundation to donate $\$ 100,000$ annually. ${ }^{89}$ Like Amorphia, NORML embraced countercultural retailing for fundraising. The group marketed its own "line of marijuana-related paraphernalia," mostly T-shirts, posters, and buttons that employed the rhetoric of radical activism and countercultural freedom with messages like "Liberate Marijuana." NORML distributed the paraphernalia primarily to head shops, a decision that Stroup supposedly agonized over initially, but eventually opted for because, as a friend remarked, "you can't play polite image games while people are rotting in jail." NORML also bought the distribution rights for Reefer Madness, the cult 1936 film that young audiences had revived on the midnight movie circuit for its unintentionally laughable and unrealistic depictions of the evils of pot. The film grossed $\$ 100,000$ at the box office in 1972 alone. 
And it was no accident that the name of NORML's national newsletter - The Leaflet - referred both to its role as a newsletter and to head shops' biggest seller, rolling paper. ${ }^{90}$ While NORML did benefit from its countercultural connections, it was generous funding from the Playboy Foundation and a rather conventional but effective legislative lobbying strategy that allowed it to assume unofficial leadership of the marijuana reform movement by the middle of the 1970s.

The burgeoning decriminalization movement was certainly important to head shops, but the biggest boost to their business in these years came from High Times, the self-declared "only magazine dedicated solely to getting high." 91 High Times premiered in fall 1974 at New York's annual National Boutique Show, an annual trade convention and "vertical Woodstock Festival" that had drawn countercultural boutique owners, crafts-makers, head shop distributors, and smoking accessories producers to the 25-story McAlpin Hotel in Manhattan since $1970 .{ }^{92}$ The magazine's founders included Andy Kowl, editor of Long Island's Express underground newspaper, and Tom Forcade, the longtime head of the Underground Press Syndicate and an active Yippie and all-around countercultural eccentric. ${ }^{93}$ High Times, its editors declared, was "where dope, sex and politics melt, mingle and fuse into ideas too hot for the official culture to handle." 94 Issues featured centerfold spreads of exotic and expensive varieties of marijuana, advice columns on how to intensify and enhance drugs' effects, and interviews with musicians, writers, and other countercultural figures. Demand for High Times skyrocketed quickly after its debut, and in late summer 1975 its fifth issue had a print run of 250,000 . $^{95}$

High Times provided a communications network for head shops and their customers all over the country. Before the magazine emerged, the marketplace for "head gear" - essentially the paraphernalia for getting high - had been a small, fractured cottage industry of highly localized retailers and a handful of producers and distributors with regional or national reach. Yet by advertising in High Times, paraphernalia producers and distributors could now reach a national audience of stoners, while local head shops could find suppliers much more easily, and vice versa. As a result, the paraphernalia business became significantly more competitive, since retailers could now comparison-shop much more easily. By 1977, the overwhelming majority of the High Times' advertising revenue came from head shops and paraphernalia producers, and around half the pages of every issue featured ads. ${ }^{96}$ That year, the magazine's circulation rose to 400,000 , but an independent marketing firm estimated that 10 people read each copy of the magazine, so that its per-issue readership was closer to four million. ${ }^{97}$

The demand for rolling papers and pipes had grown so much that many retailers other than head shops now stocked marijuana accessories, too. Paraphernalia sold briskly at record stores, tobacco shops, drug stores, convenience marts, and even at grocery stores like A\&P and general merchandisers such as K-Mart and Sears, Roebuck, \& Company. Larry Posner, a director of the National Association of Tobacco Distributors and onetime employee of the E-Z Wider rolling paper company, estimated in 1978 that "ninety percent of the cigarette paper in this country is not sold through the paraphernalia industry." 98 Yet while the paraphernalia industry enjoyed close ties to tobacco distributors, tobacconists hesitated to acknowledge publicly that products like the E-Z Wider were intentionally marketed to marijuana consumers. ${ }^{99}$ 
As High Times declared in 1978,

the nuts-and bolts business of selling things to help you get stoned ... [has] exploded into the most phenomenal industrial success story of the decade. As Detroit continues to recall cars and the oil companies quiver over depletion allowances, the business of getting high continues to expand.

Indeed, paraphernalia had become nothing less than a "slick form of capitalism with a multi-billion-dollar potential the government and Fortune 500 have yet to decipher."100 Meanwhile, the decriminalization movement was enjoying unprecedented success, with 10 states following Oregon in decriminalizing marijuana from 1974 to 1978 . Head shops proliferated all over the country, and numbered as many as 30,000 by 1979 according to one estimate. ${ }^{101}$ For many advocates of marijuana, pot appeared to be on the verge of national decriminalization, even legalization, by the late $1970 \mathrm{~s}$.

\section{IV}

Head shops and the marijuana reform movement achieved broad political and social acceptance in tandem with each other in the second half of the 1970s. In the process, however, they lost much of their connection to the radicalism and counterculture of the late 1960s and early 1970s. Some observers argued that pot and paraphernalia should become parts of the established, licit economy - or even that they had already done so. "Paraphernalia," the New York Times declared in 1976, was "no longer a hippie phenomenon but a business for young capitalists." And even if the head shop trade "grew out of the confrontation era of the sixties and still smacks a bit of confrontation politics," an attorney for the paraphernalia industry told Congress in 1979, it would "rapidly become more responsible and traditional" in the 1980s. ${ }^{102}$ Some marijuana enthusiasts began to worry that pot had become too commercial, that with rapidly growing acceptance smokers had lost sight of pot's political and spiritual potential. "The new marijuana ethic today is closely allied to a general consumerism," one High Times contributor lamented in 1979 , warning that it was eventually "bound to intrude on the consciousness-altering ritual of smoking weed." 103

Head shop owners and legalization advocates, however, would never have to face the perils of going truly mainstream. In 1976, a handful of parents in suburban Atlanta organized a group they called DeKalb Families in Action, vowing to protect their teenage children from the so-called "commercialized drug culture" of head shops, High Times, and widespread marijuana use. ${ }^{104}$ Led by Martha Keith Schuhard, a professor of English at Emory University, the group responded to head shops and other local businesses selling drug paraphernalia with pickets and door-to-door leafleting. Families in Action organized a highly effective campaign to convince DeKalb County officials to revoke head shops' business licenses, after which they persuaded state legislators to pass a bill banning all drug paraphernalia. Although the law was ruled unconstitutional, it nonetheless drove many head shops in the area out of business. Schuchard also began to correspond with Robert DuPont, the head of the federal National Institute on Drug Abuse, who in turn commissioned Schuchard to write a drug prevention handbook for families called 
Parents, Peers, and Pot. The book reportedly became the agency's most requested publication ever. ${ }^{105}$

Families in Action had produced an effective blueprint for parents throughout America to organize against head shops. Police raids on the businesses increased dramatically across the country, and drug paraphernalia and head shops even became the subject of Congressional hearings in 1979. ${ }^{106}$ As head shops increasingly found themselves in battles with state and local authorities, NORML was at the forefront of organizing head shops' legal defenses, providing them with strategic advice and attorneys. ${ }^{107}$ The Department of Justice under Jimmy Carter drafted model legislation for states to restrict and regulate head shops, which the agency promoted even more aggressively during the Reagan administration, especially after the Supreme Court validated drug paraphernalia bans in $1982 .{ }^{108}$ Anti-paraphernalia laws, the Court decided, hinged on demonstrating the seller's or the purchaser's intent for illegal substances to be consumed with said paraphernalia. Any pipe, for instance, could theoretically be used to smoke tobacco and thus was legal, but a so-called isomerizer that was advertised to boost marijuana's cannabinoid potency could be prohibited. By 1987, all but six states had passed laws banning drug paraphernalia. $^{109}$

The attacks on head shops became one of the first fronts in the War on Drugs that Ronald Reagan would famously declare early in his first term. ${ }^{110}$ In a federal survey released by the Department of Justice in 1987, 55 percent of sheriffs and police commissioners responded that head shops had operated in their jurisdictions prior to the enactment of paraphernalia laws. After the passage of such laws, however, nearly half of these jurisdictions no longer had any head shops. Paraphernalia sellers' greatly increased risk of criminal penalties, as well as the financial costs of hiring defense attorneys, forced many smaller head shops to close for good, in turn fueling a wave of consolidation in the business that favored larger retailers. ${ }^{111}$ Decriminalization meanwhile virtually ground to a halt. After 1978, not a single state would eliminate criminal penalties for recreational marijuana use for over two decades, until Nevada finally did so in 2001. ${ }^{112}$

Since 2012, several states have decriminalized and even legalized marijuana, ushering in a new chapter in the history of politically active business owners and the marijuana rights movement. National media outlets are awash with profiles of entrepreneurs in Colorado and Washington State eager to recast the marijuana business as a clean-cut, reputable, and legitimate line of work. "We're weeding out the stoners," explained Olivia Mannix, one of two founders of Cannabrand, a Colorado advertising agency seeking to promote a more positive image for marijuana businesses. Marijuana retailers have their own trade group, the National Cannabis Industry Association, which advocates for reforming the laws governing both marijuana consumers and businesses. There is even a marijuana retail trade school in Oakland, California called Oaksterdam, which one writer for The Atlantic has described as having an "atmosphere of purposeful endeavor [that] was like what you might find at a night-school business class of aspiring franchisees."113 In 2015, the marijuana business is verging on a level of respectability that it approached in the late 1970 s.

It remains unclear, however, whether marijuana reform will necessarily produce wider acceptance or legal gains for head shops. In Maryland, for instance, the state legislature removed criminal penalties for marijuana possession in April 2014, but Governor Larry Hogan vetoed a bill to decriminalize marijuana paraphernalia one 
year later. ${ }^{114}$ Many of the state's head shops and so-called "vape shops" specializing in vaporizers still darken or cover their entrances and store windows to make them inscrutable to passersby, reinforcing the perception that the business they do is morally if not legally questionable and best hidden from the public. And even in states where marijuana is now fully legal, the dispensaries that sell pot still "look like underground abortion clinics," as one of the founders of Cannabrand concedes. Meanwhile, the Drug Enforcement Administration has carried out Project Synergy since 2013, a national campaign of confiscations and raids against head shops and other sellers of "synthetic designer drugs" not approved by the federal Food and Drug Administration. ${ }^{115}$ Although marijuana sellers may enjoy newfound legal and social acceptance in some American states, head shops remain taboo and legally precarious in much of the country.

V

In the late 1960s and early 1970s, hippie entrepreneurs and their customers embraced head shops as vital commercial sites where they could build countercultural communities and pursue higher states of consciousness. Enterprising visionaries like Ron and Jay Thelin sought to offer clear alternatives to the alienation and conformity of America's dominant consumer culture with their unconventional stores. In addition, head shop owners envisioned their stores as political vehicles for promoting the anti-war cause and expanding the movement for drug law reform. Legalization groups like Amorphia and NORML, in turn, considered head shop owners some of their closest allies. Head shops' remarkable growth in the middle and late 1970s signaled just how much social and commercial influence the counterculture enjoyed long after the halcyon days of the Summer of Love. While head shops boomed in the late 1970 s, however, their owners lost much of their countercultural yearning for radical idealism, and they grew much more sensitive to the demands of long-term financial stability and conventional entrepreneurship. Meanwhile, head shops' rise sparked a powerful backlash from parents' groups, police, and legislators. As fitting symbols of the counterculture's larger legacy, the sellers of bongs and rolling papers became convenient early targets in the War on Drugs of the 1980s.

Indeed, head shops offer a revealing case study of how countercultural entrepreneurs hoped to elevate American business culture and directly challenge state and police power. While these businesses were not opposed to turning a profit, the communitarian idealism and engagement of their early years undermined the common charge that so-called hip capitalists were little more than apolitical sell-outs and dupes. Although head shops demonstrated little of their original countercultural radicalism by the late 1970s, the intensity of the backlash they faced suggests the political threat they represented to many Americans. Consequently, by taking head shops seriously, we stand to gain a more sophisticated understanding of the counterculture's deeply political approach to drugs, entrepreneurship, and public space.

\section{Acknowledgments}

I would like to thank Lauren Du Graf, Andy Kowl, Jay Thelin, Jeremy Varon, Charlie McGovern, and the anonymous manuscript referees of The Sixties for their helpful and constructive comments on this work. 


\section{Notes}

1. James S. Kaplan, "The Corner Store: A Bronx Deli Mixes Food and Friendliness for Profit, but the Times Are Changing," Wall Street Journal, September 4, 1970, 20; "The Corner Store: A Philadelphia Ghetto and Its Problems Are a Way of Life for a Busy Undertaker," Wall Street Journal, September 2, 1970, 26.

2. Art Glickman, "The Corner Store: Mod Boutiques in Lansing Turns Tidy Profit by Offering Clients a Feeling of Freedom," Wall Street Journal, September 17, 1970, 34.

3. Ibid.

4. Farber, "Building the Counterculture."

5. Davis, From Heads Shops to Whole Foods.

6. "The Age of Acquireous," Good Times, December 11, 1970, 10; J. Kaye Faulkner, "A Rose by Any Other Name...," Northwest Passage, February 7, 1972, 8; "Money vs. People," Georgia Straight, September 10-17, 1969, 6.

7. Jane Wilson, "Commerce in Hippieland," Los Angeles Times, January 28, 1968, B16-B21; Gordon Grant, "Girl's Small Psychedelic Shop Stirs Furore in San Clemente," Los Angeles Times, July 18, 1968, B10; Buck Meloy, "This Is a Capitalist Society, So We're Capitalists...," Northwest Passage, February 7, 1972, 10.

8. On the counterculture and business, see Farber, "Building the Counterculture;" Frank, The Conquest of Cool; Binkley, Getting Loose; Kramer, Republic of Rock; Turner, From Counterculture to Cyberculture; Kirk, Counterculture Green; Meriwether, "The Counterculture as Local Culture." On the history of marijuana, see Booth, Cannabis; Lee, Smoke Signals; Sloman, Reefer Madness.

9. "Life Drugs, Death Drugs," originally published circa 1973, Blacklisted News, 672; Sinclair, Marijuana Revolution, 16-18; Mike Minnich, "Prisoners Freed - Free Weed!," Ann Arbor Sun, April 13-27, 1972, 5.

10. “Introducing ... High Times," High Times, Fall 1974, 10.

11. Drug Paraphernalia, 5, 87; "11 States Decriminalize Marijuana Possession," Los Angeles Times, September 30, 1981, H22. Decriminalization of marijuana reduced individual possession for non-medical minor possession to a civil penalty without legalizing it outright.

12. Jay Thelin, interview with author, 11 September 2014; Leary et al., The Psychedelic Experience, 9, 68.

13. Michael Fallon, "A New Paradise for Beatniks," San Francisco Examiner, September $5,1965,5$.

14. Thelin, interview with author.

15. Cohen, "The San Francisco Oracle," xxv.

16. Thelin, interview with author; Jay Thelin, interview with Michael Klassen, 1 August 2011. Accessed May 18, 2014, http://www.billiondollarhippie.com/interviews/jay-the lin/; Perry, Haight-Ashbury, 76.

17. Thelin, interview with author.

18. Cohen, "The San Francisco Oracle," xxx; The Maze: Haight/Ashbury, KPIX-TV, 1967, San Francisco Bay Area Television Archive. Accessed January 3, 2014, https://diva.sfsu.edu/collections/sfbatv/bundles/189371.

19. Wolf, Voices from the Love Generation, 217.

20. San Francisco Bay Area Television Archive, "Psychedelic Generation Gap," originally aired on KRON-TV, circa 1967. Accessed May 18, 2014, https://diva.sfsu.edu/collec tions/sfbatv/bundles/189594.

21. Thelin, interview with author.

22. "A Prophesy of a Declaration of Independence," S.F. Oracle, September 20, 1966, 12; Jay Thelin, interview with author; Cohen, "The San Francisco Oracle," xxv.

23. Perry, Haight-Ashbury, 97; Lee, Acid Dreams, 149.

24. "The Psychedelicatessen," Time, February 24, 1967, 96.

25. Lewis, "Capitalism, Contra-Culture," 88-9.

26. Thelin, interview with author.

27. Perry, Haight-Ashbury, 132.

28. Ibid., 189; The Maze: Haight/Ashbury.

29. Echols, Shaky Ground, 44-6; Kramer, Republic of Rock, 98; Staller, Runaways, 36-41, 71-99. 
30. Thelin, interview with Klassen; Thelin, interview with author.

31. Hoffman, We Are the People, 261.

32. Perry, Haight-Ashbury, 244.

33. Louria, The Drug Scene, 42-3.

34. Buffalo Chip 1:1 (December 1967).

35. Abel, A Marihuana Dictionary, 49.

36. John Kifner, "The Drug Scene: Many Students Now Regard Marijuana as a Part of Growing Up," New York Times, January 11, 1968, 18; "Commerce in Hippieland," B16-B21.

37. Angela Taylor, "Bells, Books and Candles: Psychedelia on Sale," New York Times, August 16, 1967, 44; Dan Lackey, interview with author, 15 August 2013; "Girl's Small Psychedelic Shop," B2; "Commerce in Hippieland;" "Head Shop Busted," Los Angeles Free Press, December 26, 1969, 6; Mike Goodman, "Youngsters of All Ages Free to Browse among Hashish Pipes, Obscene Comic Books and Posters," Los Angeles Times, April 9, 1972, SF_C1.

38. Bob Cooley, "Psychedelic Shop New Eugene 'Happening," Eugene Register-Guard, February 19, 1967, 3A; Thelin, interview with author; Lewis, "Capitalism, Contra-Culture," 88; "Commerce in Hippieland," B17.

39. Hoffman, Steal This Book, 32.

40. "Commerce in Hippieland," B16; Paul Wilkes, "Baltimore's Disconnecteds: One Can't Remember His Last Address, ... ," The Baltimore Sun, December 17, 1967, 229; Clarence Newman, "Call It Psychedelic and It Will Sell Fast, Some Merchants Say: ... ," Wall Street Journal, February 9, 1967, 1; Lewis, "Capitalism, Contra-Culture."

41. "Commerce in Hippieland," B17.

42. "Baltimore's Disconnecteds," 230; "Bells, Books and Candles," 44.

43. Cooley, "Psychedelic Shop;" "Grove's Head Shop - Another World," The Miami News, October 10, 1967, 8-C; Judy Hippler, "'Head Shop' for Hippies Lures the Squares, Too," The Atlanta Constitution, July 27, 1968, 6L; The Maze: Haight/Ashbury.

44. Schou, Orange Sunshine, 66-8, 71-2. See also Ray Ripton, "Head Shops Find Better Business in Diversifying," Los Angeles Times, May 7, 1972, CS1; "Youth Admits Selling Dope," The Miami News, July 24, 1968, 6-C.

45. Marshall Chapman, "Keeping Secrets: Why You Should Never Tell a Soul about Your Favorite Hangout," Garden \& Gun, August-September 2009; Naison, White Boy, 124.

46. Staller, Runaways.

47. Partridge, The Hippie Ghetto; Lofland, "The Youth Ghetto;" Mele, Selling the Lower East Side, 153-79; Ligeti, "Spatial Empowerment;" Scott, "Remaking Urban in the American West." On street harassment of hippies and activists, see Brown, "The Condemnation and Persecution of Hippies."

48. "Head Shop Busted," Los Angeles Free Press, December 26, 1969, 6; Wallace Author, "Head Shop Harassed," Space City, August 3, 1971, 3; Vitti, The Passage, 351-4; "Phluph Bombed," Dallas Notes, September 2, 1970, 5; "Undercover Pot Head Details Hippie Types," Daytona Beach Morning Journal, April 24, 1968, 6.

49. "Girl's Small Psychedelic Shop," B10.

50. Wolf, Voices from the Love Generation, 186; "Five Decades of Haight Memories with Gallery 683's Harry Strauch," Hoodline, November 19, 2014. Accessed March 6, 2015, http://hoodline.com/2014/11/five-decades-of-memories-with-gallery-683-s-harrystrauch.

51. "The Age of Acquireous," 10.

52. "Pot Counter-Revolutionary," Eyewitness, June 1970, 5; Levin, Cold War University, $142-3$.

53. "IN MEMORIAM for Superspade and John Carter," The San Francisco Oracle, 9, August 1967, 4.

54. S. Cheer, "(II) Boston to Atlanta," Great Speckled Bird, March 17, 1968. See also "Pot Counter-Revolutionary," Eyewitness, June 1970, 5; Levin, Cold War University, $142-3$. 
55. "Commerce in Hippieland," B16-B17; “"Head Shop' for Hippies," Ray Ripton, "Head Shops Find Better Business in Diversifying," Los Angeles Times, May 7, 1972, CS1; Doug Brown, interview with author, 2 June 2014; McMillian, Smoking Typewriters, 124.

56. "Why Students Act That Way: A Gallup Study," US News \& World Report, June 2, 1969, 35

57. Eastland, "Introduction," v.

58. Krogh, The Day Elvis Met Nixon, 36.

59. Sinclair, Marijuana Revolution, 8-19; Thelin, interview with author.

60. Sinclair, Marijuana Revolution.

61. Blacklisted News, 514.

62. "1973 Marijuana Arrests Approach One-Half Million Mark," The Leaflet: The Publication of the National Organization for the Reform of Marijuana Laws, July/August/September 1974, 1.

63. White, Marijuana Puff In.

64. Lee, Smoke Signals, 97-102; The Marijuana Newsletter, Issue \#2, March 15, 1965, 1.

65. "Randolfe Wicker: From Pot to the Days of Wine and Cloning," GayToday.com, October 1, 2002. Accessed March 22, 2015, http://www.gaytoday.com/interview/ 100102 in.asp.

66. "Lee Otis Johnson Still Behind Bars," The Southern Patriot, September 1, 1969, 7; "Release: Lee Otis Johnson," Great Speckled Bird, January 31, 1972, 4.

67. "Free Otis Lee Johnson: Houston's Black Political Prisoner," 1969, Student Non-Violent Coordinating Committee - Lee Otis Johnson Defense Committee, 1970-72, Social Protest Collection, 1943-82, Carton 6, Reel 21, Folder 23, the Bancroft Library, University of California, Berkeley.

68. "Lee Otis Johnson: 4 Years for One Joint," The Great Speckled Bird, July 26, 1972, 22; John Schwartz, "Lee Otis, Free," Texas Monthly, August 2002.

69. John Sinclair, "Free the Weed 48," February 21, 2015. Accessed March 22, 2015, $\mathrm{http} / / / \mathrm{www} . j o h n s i n c l a i r . u s / c o m p o n e n t / c o n t e n t / a r t i c l e / 3-n e w s f l a s h / 1057-f r e e-t h e-w e e d-$ 48.html; Lee, Smoke Signals, 100.

70. "John Sinclair: Introducing a Counter-Culture Legend," September 19, 2013. Accessed March 22, 2015, http://sensiseeds.com/en/blog/john-sinclair-introducing-acounter-culture-legend/.

71. Sinclair, 10 Years for 2 Joints, 1-3.

72. Sinclair, Guitar Army, 89-91.

73. Sinclair, 10 Years for 2 Joints, 3-5.

74. Sinclair, Message to the People, 9.

75. "Free John Sinclair," Marijuana Review, October-December 1969, 2; Marijuana Review, January-June 1970, cover.

76. "Dec. 1971-Dec. 1972: Year of Historic Accomplishments," Ann Arbor Sun, December 1-15, 1972, 2.

77. "Michigan to Free Inmates," New York Times, April 8, 1972, 32.

78. "We Won!!," Ann Arbor Sun, April 13-27, 1972, 2.

79. "Dec. 1971-Dec. 1972: Year of Historic Accomplishments," 2; "Ann Arbor Eases Marijuana Curbs: Maximum Penalty Is Fine of \$5 - Tickets Issued," New York Times, September 24, 1972, 42.

80. “Are You Ready for ... Amorphia," Marijuana Review, October-December 1969, 16.

81. Everett R. Holles, "Drive to Legalize Marijuana Is Funded by Nonprofit Company in California," New York Times, October 10, 1972, 19.

82. "When Reformers Fall Out," New York Times, March 11, 1973, 273, 356.

83. Mike Aldrich, "Acapulco Gold," Marijuana Review, January-June 1971, 11.

84. "What You Can Do to Help Legalization," July-September 1971, Marijuana Review, 12.

85. “Acapulco Gold," 11.

86. "Drive to Legalize Marijuana," 19.

87. "Death Penalty Approved; Coast Environmental Plan Winning," Los Angeles Times, November 8, 1972; Baum, Smoke and Mirrors, 73. 
88. "Drive to Legalize Marijuana," 19; "Oregonians Take Law Easing Marijuana Penalties in Stride," Los Angeles Times, September 9, 1973, 1.

89. Patrick Anderson, "The Pot Lobby," New York Times, January 21, 1973, E8.

90. Ibid., E9; The Leaflet: The Publication of the National Organization for the Reform of Marijuana Laws, July, August, September 1973, 6.

91. "Introducing ... High Times," 10.

92. "Boutique Show Slated in New York," Los Angeles Sentinel, June 11, 1970, C4; Mike Jahn, "Sounds of the Seventies: 'Gang' Outlasts Howls," The Baltimore Sun, June 25, $1972,49$.

93. McMillian, Smoking Typewriters, 115-39; Andy Kowl, interview with author, 2 August 2013; Grissim, We Have Come for Your Daughters, 111; Forcade, Underground Press Anthology, title page.

94. "The Most Dangerous Magazine in America," High Times, November 1977, 29.

95. Andy Kowl, interview with author, 3 August 2013; High Times, August/September 1975.

96. See, for example, High Times issues from January and July 1977; Kowl, interview; Daniel Machalaba, "The Pot Trade," Wall Street Journal, July 29, 1980, 1.

97. "It's Official: 4 Million People Read High Times," High Times, September 1978, DK10; "The Pot Trade," 1.

98. Michael Antonoff, "A Smoldering Battle over Rolling Paper Technology," New York Times, December 17, 1978, F3.

99. "Giving Consumer Easy-to-Use Product Is the Basis of Robert Burton Success," United States Tobacco Journal, October 5, 1978, 1.

100. A. Craig Copetas, "Paraphernalia '78," High Times, October 1978, 54.

101. Drug Paraphernalia, 5, 87

102. Anthony Astrachan, "Pot Luck," New York Times, March 21, 1976, 186; Drug Paraphernalia, 56.

103. Sloman, Reefer Madness, 328.

104. Schuchard, Parents, Peers, and Pot, 26-8.

105. "Parents Criticize 9 Stores," The Atlanta Constitution, November 23, 1977, 8A; Lucius Lomax, "DeKalb Drug Fighter Urges Parents to Search Their Children's Bedrooms," The Atlanta Constitution, May 28, 1978, 4B; Tom Crawford, "Head Shops on Down Trip in DeKalb," The Atlanta Constitution, April 23, 1978, 5B; Schuchard, Parents, Peers, and Pot; Baum, Smoke and Mirrors, 123.

106. Drug Paraphernalia, 1.

107. "Paraphernalia Trade Assoc. Hires Stroup to Lobby," Paraphernalia Digest - Newsmagazine of the Industry, January 1979, 1, in author's possession; the Indiana Chapter of NORML also filed suit along with the head shops Headstone Friends, the Peace Chief Shop, and Heads Up Unlimited against the state of Indiana in 1975 when it became the first state in the country to ban purported marijuana paraphernalia. See Indiana Chapter, NORML, et al. v. Sendak, No. TH 75-142-C

United States District Court for the Southern District of Indiana, Terre Haute Division, 1980 US Dist. LEXIS 16663, 4 February 1980.

108. Greg Witcher, "Ruling's Effect Locally Is Debatable," The Atlanta Constitution, March 4, 1982, 1A, 11A; Hoffman Estates v. Flipside, Hoffman Estates, No. 801681, Supreme Court of the United States, 455 US 489; 102 S. Ct. 1186; 71 L. Ed. 2d 362; 1982 US LEXIS 78; 50 USLW 4267, 9 December 1981, Argued, 3 March 1982, Decided, Petition for Rehearing Denied 26 April 1982.

109. Healey, "Controlling Drug Paraphernalia," 319.

110. On the history of marijuana's prohibition, see Baum, Smoke and Mirrors; Bonnie and Whitebread, The Marijuana Conviction; Himmelstein, The Strange Career of Marihuana; Massing, The Fix; Frydl, The Drug Wars in America.

111. Healey, "Controlling Drug Paraphernalia," 322-4.

112. Ed Vogel, "New State Law Eases Penalties on Marijuana," Las Vegas Review-Journal, September 30, 2001, 1B.

113. Jessica Bennett, "In Colorado, a Rebranding of Pot Inc.," New York Times, October 3, 2014; Joshua Greene, "Cannabusiness," The Atlantic, April 2009. 
114. Pamela Wood, "Marijuana Paraphernalia Bill Advances," Baltimore Sun, April 11, 2015. Accessed May 22, 2015, http://www.baltimoresun.com/news/maryland/politics/ blog/bal-marijuana-paraphernalia-bill-advances-20150411-story.html.; "Governor Larry Hogan Vetoes Six Bills." Accessed May 22, 2015, http:/governor.maryland.gov/ 2015/05/22/governor-larry-hogan-vetoes-six-bills/

115. "DEA News: Huge Synthetic Drug Takedown," May 7, 2014. Accessed May 15, 2015, http://www.dea.gov/divisions/hq/2014/hq050714.shtml; "In Colorado, a Rebranding of Pot Inc."

\section{Notes on contributor}

Joshua Clark Davis is an assistant professor of history at the University of Baltimore. His forthcoming book, From Head Shops to Whole Foods: Activist Entrepreneurs of the 1960s and '70s, will be published in Columbia University Press's Studies in the History of US Capitalism series in 2016.

\section{References}

Abel, Ernest L. A Marihuana Dictionary: Words, Terms, Events, and Persons Relating to Cannabis. Westport, CT: Greenwood Press, 1982.

Baum, Dan. Smoke and Mirrors: The War on Drugs and the Politics of Failure. Boston, MA: Little, Brown, 1996.

Binkley, Sam. Getting Loose: Lifestyle Consumption in the 1970s. Durham, NC: Duke University Press, 2007.

Blacklisted News, Secret History: From Chicago to 1984: The New Yippie! Book. New York: Bleecker, 1983.

Bonnie, Richard J., and Charles H. Whitebread. The Marijuana Conviction: A History of Marijuana Prohibition in the United States. Charlottesville: University Press of Virginia, 1974.

Booth, Martin. Cannabis: A History. London: Doubleday, 2003.

Brown, Michael E. "The Condemnation and Persecution of Hippies." Trans-Action (Sep. 1969): 33-46.

Cohen, Allen. "The San Francisco Oracle: A Brief History." In The San Francisco Oracle, Facsimile Edition: The Psychedelic Newspaper of the Haight-Ashbury, 1966-1968. Berkeley: Regent Press, 1991, xxv-lvi.

Davis, Joshua Clark. From Head Shops to Whole Foods: Activist Businesses of the 1960s and '70s and the Roots of the New Economy. New York: Columbia University Press, forthcoming.

Drug Paraphernalia: Hearing before the Select Committee on Narcotics Abuse and Control, 96th Congress, Washington, DC: US Government Printing Office, 1980.

Eastland, Senator James O. "Introduction." In Marihuana-Hashish Epidemic and Its Impact on United States Security: Hearings Before the Subcommittee to Investigate the Administration of the Internal Security Act and Other Internal Security Laws of the Committee on the Judiciary, v-xx. Washington, DC: US GPO, 1974.

Echols, Alice. Shaky Ground: The '60s and Its Aftershocks. New York: Columbia University Press, 2002.

Farber, David. "Building the Counterculture, Creating Right Livelihoods: The Counterculture at Work." The Sixties: A Journal of History, Politics, and Culture (Spring 2013): $1-24$.

Faulkner, J. Kaye. 1972. “A Rose by Any Other Name...” Northwest Passage, February 7, p. 8.

Forcade, Thomas K. Underground Press Anthology. New York: Ace Books, 1972.

Frank, Thomas. The Conquest of Cool: Business Culture, Counterculture, and the Rise of Hip Consumerism. Chicago: University of Chicago Press, 1997.

Frydl, Kathleen. The Drug Wars in America, 1940-1973. Cambridge: Cambridge University Press, 2013. 
Glickman, Art. 1970. “The Corner Store: Mod Boutiques in Lansing Turns Tidy Profit by Offering Clients a Feeling of Freedom." Wall Street Journal, September 17, p. 34.

Grissim, John. We Have Come for Your Daughters: What Went Down on the Medicine Ball Caravan. New York: Morrow, 1972.

Healey, Karen Murphy, "Controlling Drug Paraphernalia." In Handbook of Drug Control in the United States, edited by James Inciardi, 317-26, Westport, CT: Greenwood Publishing Group, 1990.

Himmelstein, Jerome L. The Strange Career of Marihuana: Politics and Ideology of Drug Control in America. Westport, CT: Greenwood Press, 1983.

Hoffman, Abbie. Steal This Book. New York: Pirate Editions, 1971.

Hoffman, Nicholas Von. We Are the People Our Parents Warned Us Against. Chicago, IL: Quadrangle Books, 1968.

Kirk, Andrew. Counterculture Green: The Whole Earth Catalog and American Environmentalism. Lawrence: University of Kansas Press, 2007.

Kramer, Michael. Republic of Rock: Music and Citizenship in the Sixties Counterculture. Oxford: Oxford University Press, 2013.

Krogh, Egil. The Day Elvis Met Nixon. Bellevue, WA: Pejama Press, 1994.

Leary, Timothy, Richard Alpert, and Ralph Metzner. The Psychedelic Experience: A Manual Based on the Tibetan Book of the Dead. New York: University Books, 1964.

Lee, Martin. Smoke Signals: A Social History of Marijuana - Medical, Recreational, and Scientific. New York: Scribner, 2012.

Levin, Matthew. Cold War University: Madison and the New Left in the Sixties. Madison, WI: University of Wisconsin Press, 2013.

Lewis, George H. "Capitalism, Contra-Culture, and the Head Shop: Explorations in Structural Change." Youth and Society 4, no. (1) (Sep. 1972): 88-9.

Ligeti, Andrew E. "Spatial Empowerment and the Los Angeles Counterculture, 1965-1967: The Search for Hallowed Ground in the City of Angels." PhD diss., California State University, Northridge, 2012.

Lofland, John. "The Youth Ghetto." Journal of Higher Education 39, no. (3) (March 1968): 121-43.

Louria, Donald B. The Drug Scene. New York: McGraw-Hill, 1968.

Massing, Michael. The Fix. New York: Simon and Schuster, 1998.

McMillian, John. Smoking Typewriters: The Sixties Underground Press and the Rise of Alternative Media in America. Oxford: Oxford University Press, 2011.

Mele, Christopher. Selling the Lower East Side: Culture, Real Estate, and Resistance in New York City. Minneapolis, MN: University of Minnesota Press, 2000.

Meriwether, Nicholas G. "The Counterculture as Local Culture in Columbia, South Carolina." In Rebellion in Black and White: Southern Student Activism in the 1960's, edited by Robert Cohen, and David J. Snyder, 218-234, Baltimore: Johns Hopkins University Press, 2013.

"Money vs. People." 1969. Georgia Straight, September 10-17, p. 6.

Naison, Mark. White Boy: A Memoir. Philadelphia, PA: Temple University Press, 2002.

Partridge, William L. The Hippie Ghetto: The Natural History of a Subculture. New York: Holt, Rinehart and Winston, 1973.

Perry, Charles. The Haight-Ashbury: A History. New York: Rolling Stone Press, 1984.

Schou, Nick. Orange Sunshine: The Brotherhood of Eternal Love and Its Quest to Spread Peace, Love, and Acid to the World. New York: Thomas Dunne Books, 2010.

Schuchard, Marsha K. Parents, Peers, and Pot. Rockville, MD: US Dept of Health, Education, and Welfare, Alcohol, Drug Abuse, and Mental Health Administration, National Institute on Drug Abuse, 1979.

Scott, Amy L. "Remaking Urban in the American West: Lifestyle Politics, Micropolitan Urbanism, and Hip Capitalism in Boulder, Colorado, 1958-1978." PhD diss., University of New Mexico, 2007.

Sinclair, John. 10 Years for 2 Joints: Free John Sinclair. New York: International Committee to Free John Sinclair, 1969.

Sinclair, John. Guitar Army: Rock \& Revolution with Mc5 and the White Panther Party. Los Angeles, CA: Process, 2007.

Sinclair, John. Marijuana Revolution. Ann Arbor: Rainbow People’s Party, 1971. 
Sinclair, John. Message to the People of Woodstock Nation. Ann Arbor: White Panther Party, 1970.

Sloman, Larry. Reefer Madness: The History of Marijuana in America. Indianapolis, IN: The Bobbs-Merrill Company, 1979.

Staller, Karen M. Runaways: How the Sixties Counterculture Shaped Today's Practices and Policies. New York: Columbia University Press, 2006.

Turner, Fred. From Counterculture to Cyberculture: Stewart Brand, the Whole Earth Network, and the Rise of Digital Utopianism. Chicago: University of Chicago Press, 2006.

Vitti, Phillip M. The Passage: Memoir of a Boston Undercover Cop in the '60s. Bloomington, IN: AuthorHouse, 2012.

White, James R., III. Marijuana Puff In. San Francisco: LeMar, 1965.

Wolf, Leonard. Voices from the Love Generation. Boston: Little, Brown, 1968. 